\title{
Entre o Ritual e a ARTE ${ }^{1}$
}

\author{
Jan Cohen Cruz
}

Qualquer performance baseada na comunidade é situada em algum lugar entre a arte e o ritual. Começo com a tradição específica da arte onde se localiza este lugar. A performance baseada na comunidade, na tradição de arte popular, surge "da experiência comum que o público e o ator compartilham.... [A]quelas experiências conhecidas e familiares, são aprofundadas quando reinterpretadas" (Hall 1965, 64). A "performance popular” evoca imagens ecléticas - os adolescentes de Nova Iorque, uns tentando superar os outros cantando rap ou dançando break; atores de commedia dell'arte improvisando uma peça em um mercado na Itália do século XVI; moradores de vilarejos africanos compartilhando histórias a sombra de uma grande árvore. A performance baseada na comunidade encontra-se nesta tradição, comprometida com formas e conteúdo culturais que são expressões de um grupo de pessoas conectadas pelo local, tradição, história, e/ou espírito. Como o estudioso John Cavelti escreve em relação à cultura popular, a arte baseada na comunidade "anda na fronteira” entre "convenções e intenções” (M. Berger 1998, vii). Ou seja, tal arte combina os elementos familiares de comunidades específicas com aspetos novos e surpreendentes. Os espectadores não têm que se ver com uma inclinação artística para poder esperar que tal trabalho diga algo a eles. Os artistas não têm que suprir o público, mas, em uma relação dialética, às vezes liderar e à vezes seguir as pessoas às quais os seus trabalhos são direcionados.

Enquanto a arte popular não é sinônimo de arte baseada na comunidade, teorias sobre o que consideramos popular ajudam a esclarecer os objetivos da arte baseada na comunidade e também os preconceitos difundidos contra ela. O estudioso Raymond Williams articula cinco usos do termo popular que refletem uma variedade de atitudes relevantes ao meu assunto.

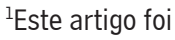
retirado do livro de Cohen-Cruz, Jan. Local Acts: community based performance in the United States. New Brunswide: Rutgers, 2005. Tradução de Daniel Yencken e Maria Brigida de Miranda. 


\section{Urdimento}

2"Departamento de Pobreza de Los Angeles". 0 acrônimo deste nome em inglês (LAPD) é o mesmo do acrônimo do Departamento de Polícia de Los Angeles.
O primeiro é o que atribui ao popular o sentido de "outro", em relação à arte erudita (Heath e Skirrow 1986, 4). Enquanto influenciado negativamente para posicionar este campo abaixo da arte erudita, esta idéia do popular também tem uma conotação positiva, revelando uma estética que não exige uma educação especial para ser apreciada. Sobre a sua companhia, composta principalmente por pessoas sem-teto, John Malpede declara que, "O fato de que muitos dos artistas do LAPD [Los Angeles Poverty Department $\left.{ }^{2}\right]$ não freqüentaram a academia - e nunca frequentarão - é, de fato, o ponto central" (Lewis 2002b). Eles providenciam o que Malpede chama da "coisa verdadeira", uma maneira de ver o mundo, informada por experiências freqüentemente duras e pouco conhecidas por pessoas que nunca viveram sem teto. $\mathrm{O}$ que as suas histórias revelam pode ser tão universal quanto os contos que pertencem à arte erudita. A escritora Vivian Gornick faz uma distinção útil entre a história - definida como "a experiência emocional que preocupe o escritor: o discernimento a sabedoria - a coisa que a pessoa tem a dizer - e a situação - 'o contexto ou circunstância” (2001, 13). Embora a situação em uma produção baseada na comunidade possa relacionar-se às circunstâncias das vidas daquelas pessoas, o que eles estão comunicando por aquelas circunstâncias poderia ser tão significativo quanto qualquer outra história. Ter base na comunidade não indica o nível de universalidade ou qualidade artística, mas simplesmente colaboração entre artistas e um grupo de pessoas conectadas de alguma maneira contínua, que contribuíram significativamente para a criação de um trabalho.

O teórico cultural Stuart Hall explica que o popular pode ser distinguido da grande arte por causa das "severas linhas de divisão dentro do nosso sistema educacional, a identificação entre cultura e classe, e a questão de climas culturais distintos entre seções diferentes da nossa sociedade estratificada" (1965, 74). Visando a construção destas divisões, Lawrence Levine escreve sobre os espaços culturais fluidos da primeira parte do século XIX que permitiram compartilhamento cultural; pessoas de classes diversas freqüentaram habitualmente produções de Shakespeare, por exemplo. Mas, cada vez mais, diferenças culturais foram utilizadas para justificar divisões de classe. Somente as formas culturais consideradas inconseqüentes intelectualmente poderiam ser compartilhadas amplamente com a população geral, e ainda assim o preço de seções distintas de poltronas limitou a possibilidade de interação e contato entre as pessoas. A cultura chegou a reforçar diferenças de classe, realçando que a arte não trata só de objetos, mas antes, a relação destes objetos com espectadores particulares, em contextos sociais reais. Percebemos esta dinâmica em uma história tão simples quanto a do encanador que foi para o Metropolitan Museum of Art de Nova Iorque em 
1897 e foi impedido de entrar porque estava vestindo macacão (Levine 1988, 185). A performance baseada na comunidade é freqüentemente percebida como popular neste sentido de ser mais baixa na hierarquia cultural, devido principalmente, à participação de pessoas fora das classes média e alta.

A segunda definição, segundo Williams, é o popular como cultura do povo, dando continuidade a uma tradição cultural sem as marcas específicas de um artista individual (Heath e Skirrow 1986, 4). Como a primeira definição de Williams, o popular como cultura do povo carrega um status mais baixo do que a arte erudita. Desafiando esta percepção, a estudiosa Yolanda BroylesGonzalez expandiu o seu foco de estudo sobre El Teatro Campesino, além da abordagem "o grande homem/textocentrismo" (neste caso, o fundador Luis Valdez e os roteiros do Campesino) para privilegiar as raízes culturais, ao posicioná-lo dentro da tradição oral mexicana operária. O trabalho de Broyles-Gonzalez tem ramificações significativas para a performance baseada na comunidade, que pode semelhantemente ser valorizado nos seus próprios termos e por suas raízes culturais. A oralidade providencia à arte baseada na comunidade o poder que falta no teatro que não está aliado a públicos particulares. Broyles-Gonzalez escreve que "A cultura oral não é tipicamente apenas de palavras faladas, mas palavras definidas pelo contex to do seu modo de vida ... engajada na cotidianeidade da vida” (1994, 5-6). Devido a sua base na vida cotidiana, em trabalho baseado na comunidade, referências comuns a populações inteiras são profundas e inúmeras. Os atores-trabalhadores rurais de El Teatro Campesino, por exemplo, souberam muito bem quais referências foram relevantes aos trabalhadores rurais "chicanos" que constituíram o seu público central. Em contraste, não é provável que atores profissionais conheçam em detalhe o que um grupo de espectadores anônimos tem em comum. A ligação com cultura do povo é um bem e não um déficit, da performance baseada na comunidade.

Segundo a terceira definição de Williams, o popular é algo direcionado a uma grande quantidade de pessoas e "apreciado por muitos" (Heath e Skirrow 1986, 4). Hall, por outro lado, argumenta contra uma formulação do popular baseada em números de espectadores. Ele acredita que a arte popular "prospera só quando públicos largamente variados encontram algo em comum e comumente valorizado na sua apreciação; uma das precondições disso sendo que as instituições que sustentam esta arte deveriam ser instituições abertas e amplamente disponíveis” (65). A diversidade dos espectadores engajados, e não a quantidade, é o fator que Hall enfatiza. Como a performance baseada na comunidade cada vez mais incorpora diversos grupos em parcerias, a popularidade neste sentido é um valor que ela compartilha. 
A popularidade medida em números trás a idéia de arte de massa e a questão da comercialização. O crítico Dominic Strinati questiona: "A emergência da cultura em forma de mercadoria significa que a rentabilidade e comercialização tomam precedência sobre qualidade, valor artístico, integridade e desafio intelectual?” Ou seria o caso onde o crescente mercado universal para cultura popular garante que ela seja verdadeiramente popular porque disponibiliza mercadorias que as pessoas realmente querem?” (3). O termo massa neste contexto se refere à sociedade da idade industrial, caracterizada por indivíduos separados fazendo as suas próprias escolhas em lugar de serem organizados em comunidades com valores coletivos e "relacionamento[s] moralmente coerentes" (Strinati 1995, 6). Arte baseada na comunidade é claramente uma alternativa ao popular no sentido de cultura da massa.

A quarta definição de Williams é o popular como oposição: “Aquele que representa uma certa forma de interesse ou experiência, versus os modos de uma cultura estabelecida ou versus um poder" (Heath eSkirrow 1986, 5). Apesar de toda a performance baseada na comunidade não ser popular neste sentido, há muitos exemplos. No final da década de sessenta, Cesar Chavez, o líder do sindicato de trabalhadores rurais "chicanos" identificou o papel de um teatro orientado a um público operário. Seguindo a tradição Mexicana da carpa, um espetáculo popular itinerante de lona, um teatro deste tipo apresentaria peças satíricas, pastelões e peças improvisadas, simpatizando com os desfavorecidos: "Com uma carpa poderíamos dizer coisas difíceis às pessoas sem ofendê-las. Poderíamos falar sobre pessoas sendo covardes, por exemplo. O que poderia ser ofensivo vira engraçado. E poderíamos ainda comunicar questões sindicais. Quando o Teatro Campesino foi fundado, eu dava às personagens iniciais nomes [tradicionais da carpa]” (Broyles-Gonzalez 1994,13). Esta categoria também é um exemplo da dinâmica popular de "convenção com invenção." Chavez queria aproximar-se da convenção familiar e prazerosa da carpa impregnando-a, porém, com um conteúdo novo, inventivo e pró-sindicato.

Em quinto lugar, Williams descreve o popular como "um mundo muito ativo de conversação e trocas cotidianas. [Isso inclui] piadas, [e] ... fofocas cotidianas" (Heath e Skirrow 1986, 5). Este entendimento do popular é aliado à estética da vida cotidiana, e, como na terceira definição, também à cultura do povo. Segundo Oscar Handlin, a cultura do povo "lidou diretamente com o mundo concreto e intensamente familiar a seu público" e com "situações comuns dentro de um padrão de vida familiar” (Hall 1965, 53). Existia uma relação direta entre ator e público, porque o material transmitido por gerações, era profundamente familiar. A cultura do povo foi ultrapassada pela cultura popular quando a arte não era mais criada pelo coletivo, mas pelo indivíduo ainda conectado ao grupo. Muitos artistas atuantes na comunidade são populares neste sentido, 
inspirando-se nas tradições culturais compartilhadas que eles manipulam de acordo com a sua habilidade artística. Um exemplo é o Teatro Pregones, que utiliza as tradições de performances Latinas como fonte e está vinculado a um público majoritariamente, mas não exclusivamente, de latino-americanos.

A performance baseada na comunidade recupera a base coletiva da arte do povo, combinando-a com um papel central para o artista como na arte popular, e, caindo em algum lugar entre as duas, continua a incorporar uma contribuição da comunidade. Hall $(1965,59)$ informa que da arte popular “Dados elementos ‘do povo' foram mantidos apesar do artista substituir o artista anônimo do povo e do 'estilo' ter sido mais do performer do que do estilo comunal. As relações aqui são mais complexas - a arte não é mais simplesmente criada pelas pessoas de classes mais baixas - mas a interação, por meio de convenções de apresentação e sensação, restabelece esta conexão. Apesar desta arte não ser mais o produto de um 'modo de vida' de uma 'comunidade orgânica', e de não ser 'feita pelo povo', continua sendo, de uma maneira não aplicável às artes eruditas, uma arte popular, para o povo.” A performance baseada na comunidade fica de um lado do continuum de teatro popular, ao qual o "público-como-comunidade” é envolvido ao máximo no processo criativo.

No lado ritualístico da arte baseada na comunidade fica a tradição da performance criada com uma comunidade para servir a uma função social ou espiritual. O ritual faz parte do que o antropólogo John MacAloon (1984,1) chama de performance cultural, "ocasiões em que, como uma cultura ou sociedade, refletimos sobre e definimos nós mesmos, dramatizamos nossos mitos e nossa história, [e] apresentamos-nos com alternativas." MacAloon observa que as performances culturais oferecem a sua comunidade algumas maneiras de mudar, e outras maneiras de permanecer a mesma. Por exemplo, no discurso bar mitzvah do meu filho, ele confirmou a sua identidade como judeu em virtude da sua ligação com a comida, os encontros de grupo, e o estudo do Torá, mesmo quando ele declarou o seu agnosticismo, beirando o ateísmo. Mesmo não sendo um discurso de bar mitzvah típico, por meio do discurso ele ofereceu à nossa congregação tanto um sentido da continuidade do Judaísmo como uma concepção alternativa ao que é ser Judeu.

O paradigma do ritual contempla o potencial intensamente engajado da performance baseada na comunidade para todos os envolvidos. Richard Schechner escreve: "Não existe um público [no ritual]. No lugar disso, existem círculos de intensidade crescente" (1973, 243). As pessoas escolhem assistir às performances no contexto de arte; são obrigados a assistir às performances no contex to do ritual. Tais performances (se sacras, como em uma missa, ou seculares, como em uma inauguração política) afirmam "as verdades compartilhadas e não questionáveis do grupo” (Myerhoff 1978, 32). A performance baseada na 
comunidade é como ritual ao surgir de uma comunidade que contextualiza a performance como parte de um projeto coletivo maior. O antropólogo Victor Turner explica porque a comunidade precisa de tais performances: "As culturas são mais amplamente expressas e tornam-se conscientes de si mesmas em seu ritual e em suas performances teatrais. [...] Uma performance é uma dialética de 'fluxo', ou seja, o movimento espontâneo em que a ação e a consciência são uma, e a 'reflexividade' na qual os significados, valores e objetivos centrais de uma cultura são vistos 'em ação', à medida que formam e explicam o comportamento" (Schechner e Appel 1980, 1).

As performances culturais também oferecem uma ligação cultural e intelectual entre as nossas vidas individuais, aqueles que vieram antes, e os que ainda estão por vir. Eu ouço as palavras hebraicas que iniciam o canto Judeu para os mortos-yisgadal, vyisgadal, shmay raba-e as lágrimas surgem. Não importa se eu acredito em Deus ou não, se permaneço fiel aos dez mandamentos, ou se moro em uma comunidade Judaica. Profundamente familiar, o canto funciona tanto como um microscópio, focando naqueles que amava e perdi, quanto como um telescópio, avistando um rio imenso de almas partidas, dando-me uma visão ampla de geração após geração. Com a ajuda daquela lente, eu tenho uma maneira particular de trabalhar a minha perda.

A dimensão ritual pode considerar a espiritualidade que a performance baseada na comunidade abrange. Por exemplo, as suas raízes no movimento de direitos civis incluiu um fundamento na igreja e liderança religiosa. Apesar de ter motivos práticos para os ativistas do movimento encontrarem-se nas igrejas - outros poucos espaços grandes estavam disponíveis para eles - um dos papéis da igreja é de reafirmar a fé. Assim também o idealismo secular é sustentado pela fé, no sentido da crença comprometida com uma visão sem nenhuma garantia sobre o que está por vir. No contexto da performance baseada na comunidade, aquela visão pode ser a esperança por um mundo melhor, com ou sem tom religioso. A dimensão ritual ao fundir passado, presente e futuro sinaliza a espiritualidade para guiar a força daquelas pessoas com os mesmos valores que tomaram a frente e lutam por algo que ainda está por vir. Nós buscamos atingir este futuro quando falamos em ser o melhor de nós, de sermos a mudança que queremos ver no mundo. As músicas que marcam os encontros e as saídas a campo de artistas baseados na comunidade freqüentemente são musicas espirituais, como aquela que John O’Neal usa há tempos em seus projetos: “Segure a minha mão enquanto corre esta corrida (repete duas vezes), porque não quero correr esta corrida em vão." O valor alocado à boa escuta neste trabalho, incorporando o outro como tão importante quanto si mesmo, é parte da criação desse tipo de mundo com uma evocação espiritual. 
O elemento ritual também carrega perigo. O desejo intenso de compartilhar a profundidade e apelo da vida expressiva de uma cultura é diminuído ao saber que coisas terríveis já foram feitas em nome de comunidades com laços muito estreitos. Às vezes uma hipnose toma conta da situação; balançando nos braços confortantes do coletivo, as fronteiras individuais desaparecem, e paramos de perceber o que no nível do pessoal teria sido reprovável. Por isso entra a arte, a outra dimensão da performance baseada na comunidade, que não demanda a conformidade com idéias essenciais.

A arte oferece uma suspensão temporária de crença, um "imagine se...” convidando participantes a envolverem-se criticamente. De fato, a arte freqüentemente interroga suposições e verdades herdadas. Como o filósofo Herbert Marcuse afirma, a arte é a prática de liberdade; a nossa melhor proteção contra um conformismo terrível está na expressão da "imaginação não-colonizada” (Becker 1994, xx). No mesmo espírito, o escritor James Baldwin fala: "O propósito da arte é expor as questões que foram escondidas pelas respostas” (Lerman e Borstel 2003, 8). O ritual puro também ofereceria respostas. O pólo da arte do continuum de performance baseada na comunidade é responsável por tornar o familiar novo. Isto é, enquanto a arte também tem tradições, é esperado que seja tão comprometida com o novo como pelo velho. Segundo a escritora Anaïs Nin, "É a função da arte renovar a nossa percepção. As coisas com as quais somos familiares, paramos de ver. O escritor agita a cena familiar e, como por mágica, conseguimos ver novos significados nela” (8). Ao apresentarem "como teatro", os artistas baseados na comunidade convidam as pessoas que não aderem a um conjunto de valores e práticas específicas como artistas e espectadores. Tal trabalho, tipicamente apresentado em locais seculares, é mais aberto do que apresentações tradicionais para crédulos. Na performance baseada na comunidade arte e ritual enlaçam qualquer projeto situado entre os dois.

O uso do espaço apóia a fusão de ritual e propósitos estéticos. O Cornerstone Theater adapta de forma criteriosa elementos de design à comunidade na qual trabalha. A sua produção de Steelbound com o Touchstone Theater em Bethlehem, Pensilvânia, foi apresentada em uma ex-fundição de ferro de 160 anos. O espaço apoiou o papel ritualístico do Steelbound, unindo o passado (a incrível história e significado daquele espaço para a comunidade), o presente (o estado atual de abandono), e o futuro (um espaço para se imaginar como prosseguir). A fundição também apoiou a produção como uma obra de arte, com prazeres estéticos - pela sua profundidade vasta, a sua altura elevada, as antigas paredes e arcos. A performance baseada na comunidade busca integrar o melhor dos dois mundos - partindo de um grupo de pessoas conectadas umas às outras de alguma forma, reafirmando um senso de valor, 
mas sem autoritarismo - nem a celebração unicamente contextualizada em si mesma, ou a obrigação inquestionável da performance cultural, nem o completamente aberto e disponível-para-ser-comprado, o acesso limitado e o âmbito individualista da arte erudita na tradição euro-americana.

Mesmo que tanto a arte como o ritual dependam da liderança de pessoas com habilidades especiais, ambos têm critérios diferentes quando se trata de participação. No ritual, todos que aderem aos valores do grupo, se tiverem habilidades especiais ou não, podem participar. Na arte, espera-se que todos os participantes, não só os lideres, tenham habilidades especiais. Por ter sua base em ambos ritual e arte, qualquer performance baseada na comunidade deve ter clareza de quem pode participar - se os membros do grupo em questão, habilidosos ou não, como no ritual, ou se somente pessoas com habilidades especiais, seja com uma afiliação coletiva específica ou não, como na arte. O propósito-chave de uma dada performance está em questão: é mais importante para os participantes terem experiência primária como no ritual, ou é melhor depender da representação de artistas treinados, como na arte, para conseguir comunicar os pontos de vista de um grupo ao um público maior que pode ter dificuldade em apreciar uma peça com qualidade artística limitada? Ou é possível propiciar uma experiência atrativa a ambos os participantes da comunidade e o público em geral?

Cada performance baseada na comunidade precisa ser clara sobre o seu objetivo primordial. O propósito do ritual é fortalecer o coletivo, e, dependendo da ocasião, talvez transformá-lo também, por participação. O propósito pode ser de literalmente atingir algo. Os propósitos da arte são diversos, mas dependem ambos da expressão pessoal do artista e de como a apresentação "funciona” para um público. Onde isso deixa a performance baseada na comunidade? Como ela pode servir a dois mestres? Quando pessoas sem treinamento artístico representam a elas mesmas, há uma limitação do potencial comunicativo da produção? Diferentes artistas têm respostas diferentes a estas questões.

Artistas podem ser inspirados pelo ritual e ainda manter os padrões de arte em um nível profissional. Liz Lerman cita com freqüência a seguinte suposição: "Eu acho que existia um tempo quando pessoas dançavam e as plantações cresciam. Eu acho que elas dançavam e era assim que elas curaram os seus filhos. Elas dançavam e era assim que se prepararam para guerra. Talvez elas dançassem principalmente porque não podiam entender o incompreensível, e talvez no momento de transformar - não interpretar - o sol em uma dança do sol, elas conseguissem entender as forças da natureza." Não obstante esta apreciação do papel ritual da dança (que acontece mesmo 
agora entre algumas culturas, como também no passado), Lerman tornouse mais comprometida com o treinamento formal dos participantes das suas peças, vislumbrando recentemente uma escola para pessoas mais idosas para que os que participam em suas credenciadas danças inter-gerações pudessem ser fisicamente mais flexíveis e capazes (2003b).

Os valores da arte e do ritual podem ser negociados ao assegurar que a participação aconteça em algum momento no processo da performance sem predeterminar qual momento. Dependendo do projeto, as pessoas podem ser pesquisadoras, fontes primárias, atores, ou participantes centrais em debates pós-espetáculo ou ter outras atividades. Enquanto apenas atores de Roadside atuam nos espetáculos Roadside, por exemplo, a interação com as comunidades é mutuamente benéfica, dando tanto às pessoas locais oportunidades de narração de histórias, quanto aos artistas de Roadside o conhecimento cultural que informa as suas produções e enriquece suas vidas. Ainda assim, certos assuntos, como quem é pago, também têm que ser abordados. Muitos grupos baseados na comunidade negociam as necessidades das pessoas para que elas possam participar. Para algumas pessoas é a questão de cuidar das crianças; para outras é transporte para o local de ensaio. Além do mais, a questão de pagamento é mais complexa do que se pensa, porque estamos acostumados a expressar o valor de algo pela compensação monetária. Os participantes têm que saber que são valorizados a despeito de receberem salários ou ajuda de custo.

A diferença entre os membros da comunidade fazerem apresentações eles mesmos ou serem representados por artistas profissionais tem seu paralelo no sistema político da democracia. Os teóricos de direito Lani Guinier e Gerard Torres explicam que enquanto na democracia representativa as pessoas votam para que um político profissional fique um mandato representando seus eleitores, na democracia participativa eles estão envolvidos diretamente pelo menos em discussões que os afetam. Guinier e Torres dão o exemplo do Teatro Fórum de Augusto Boal como um terreno fértil para democracia participativa, porque os espectadores intervêm nas situações encenadas ao propor as suas próprias idéias para resolver a situação. Guinier e Torres explicam porque isso é importante: "Conseguir envolver comunidades no processo de imaginar seu próprio futuro é um problema que a democracia deveria resolver” (2002, 219). Muitos artistas baseados na comunidade lidam com a centralidade de participação para o crescimento político ao regularmente incluir todo mundo em círculos de histórias pré ou pós-espetáculo, incluindo mesmo aqueles que não atuam no espetáculo. Em outras palavras, tanto a democracia representativa quanto a participativa são modos da performance baseados na comunidade. Os adeptos da democracia, tanto na política quanto na performance baseada na comunidade, vêem um papel tanto para profissionais 
como para os constituintes ativos. Guiner e Torres aconselham políticos profissionais a desenvolver as suas habilidades por meio do engajamento com as pessoas que eles supostamente devem representar. Comparativamente, os artistas baseados na comunidade valorizam o engajamento profundo com os participantes da comunidade, a despeito de quem irá para o palco atuar. À medida que os participantes da comunidade tenham um papel significativo, este papel não tem que ser no palco.

Existem outros fatores governando a questão de quem participa em uma produção. Para artistas baseados na comunidade cujas raízes estão na vanguarda e nos happenings, e não no teatro, é a experiência da pessoa, e não a habilidade teatral, o critério para a seleção do elenco. Uma preocupação para os artistas das duas tradições é o poder da relação com os participantes. Ao criar arte sobre um "outro" menos poderoso corre-se o risco da exploração. Suzanne Lacy dá o exemplo do dramaturgo Henrich Ibsen. A sua peça Hedda Gabler (1892) poderia ser vista como uma exploração das mulheres por representá-las a partir da posição de poder do autor. Já por outro lado, Lacy afirma que, "muitos de nós apegam-se a esta peça como uma das primeiras nas quais vemos a representação de um desejo e uma ambição frustrada, e uma personagem feminina mais complexa - assim, os artistas representam e os artistas inevitavelmente representarão algo além deles mesmos. Então, você está em uma posição de níveis” (2002). Lacy entende que o dramaturgo negro August Wilson somente quer diretores negros para suas peças, dado que diretores negros provavelmente tiveram experiências mais próximas às personagens de Wilson do que diretores brancos. Entretanto, estas práticas podem resultar no pior tipo de política de identidade que afasta grupos de pessoas que poderiam ser aliadas. Lacy questiona quão específica necessita ser a similaridade entre diretor e material; Wilson só quer diretores negros da classe operária de uma idade específica? Lacy acredita que agora os artistas de forma geral estão bastante conscientes destas negociações complexas de identidade à medida que "nós de certo modo avançamos de maneira incerta."

As políticas de identidade levantam a questão: quem é $d a$ comunidade? É necessário que os participantes compartilhem uma identidade como raça, lugar, ou etnia, no núcleo de uma peça, para poderem exercer um papel de liderança nesta empreitada ou simplesmente para poderem participar? O’Neal deu boas vindas a todas as pessoas que estavam sinceramente comprometidas com a luta pelos direitos civis para participar no Free Southern Theater. A liderança, porém, teria que emanar das pessoas que fossem da luta para liberação. Assim da perspectiva de O'Neal, o ator profissional judeu e branco Murray Levy, profundamente 
comprometido com a igualdade, era um modelo de membro exemplar do Free Southern Theater, uma organização negra com liderança afroamericana. Entretanto, Thomas Dent e outros da companhia discordaram e expulsaram todos os membros brancos.

Com freqüência é a ressonância emocional, mais do que as políticas de identidade, que determina quem faz arte e sobre o quê. Lacy comenta que o fato de um artista trabalhar com um tema como o envelhecimento não significa que tem interesse primeiramente no envelhecimento. $\mathrm{O}$ interesse pode ter a ver com a questão da exclusão, um envolvimento com "o outro" expresso por uma empatia por grupos excluídos. Como é que participantes da comunidade podem se relacionar com o artista se ele ou ela não é do mesmo lugar que eles, seja geograficamente ou no que diz respeito à etnicidade, economia ou circunstâncias? Lacy nos impele a investigar a dinâmica do de dentro/de fora com mais complexidade: "E sobre nossas identidades múltiplas? Somos de fora do quê? Muito do meu trabalho sobre raça começou com mulheres. $\mathrm{O}$ argumento poderia ser de que a raça é um definidor mais crítico. No entanto, é mais importante que nós todos trabalhemos para resolver os problemas do que excluir a participação de pessoas genuinamente comprometidas. Muitos de nós trabalhamos mais pela empatia do que pela culpa. Eu não me senti culpada em relação a negros no movimento pelos direitos civis, eu me senti completamente simpática a ele." (2002).

Negociar inclusão e exclusão, similaridade e diferença, é primordial para a performance baseada na comunidade. Os artistas que Linda Burnham produziu no espaço teatral alternativo Highways em Los Angeles queriam que as suas identidades interculturais fossem reconhecidas: "Os Latinos queriam a performance Latina de artistas Latinos, mas também insistiram em participar em projetos que misturaram todas as identidades. Isso permitiu a eles o enquadramento de 'meu povo' e de 'meu povo como partes de todos os povos.' Eles precisavam que as suas identidades fossem reconhecidas, mas também precisavam da inclusão” (2003). Às vezes o artista pode esperar identificação e no seu lugar achar diferença. Quando eu trabalhava com um grupo de mulheres recém libertas da penitenciária, uma delas perguntou se eu tinha filhos. Agradecida por poder mostrar a nossa identidade compartilhada de mães, mostrei uma foto dos meus filhos para ela. A resposta dela foi, "Dois? Que bom - ela tem dois filhos! Gêmeos??? Ela tem gêmeos! Eles tiraram meus bebês de mim”.

Existem, no entanto, outros fatores a serem investigados em relação ao de dentro e o de fora. Como se sentem as pessoas com as quais o artista 


\section{Urdimento}

trabalha? Como a posição do artista muda ao longo do tempo? Dentro de qualquer grupo, algumas pessoas serão mais dispostas do que outras a se aproximar de um novo membro. No final da década de setenta, Lacy descobriu que as pessoas da idade da avó dela na comunidade afro-americana eram com freqüência mais dispostas a criarem laços com ela do que mulheres urbanas, intelectuais na mesma faixa etária dela. Ela também descobriu que muitas pessoas tendem a adotar este raciocínio: "Sou deste lugar e então tenho o direito de falar sobre e em nome dele.” A resposta dela é:

Morei em Oakland no meio de um gueto por dez anos e 50 por cento dos meus amigos são negros. Claro que sou de fora pela questão racial, e raça tem poder, mas qual é a base para as pessoas determinarem se sou de fora? Se for raça, compreendo, mas se for pelo lugar - não é o caso. A questão verdadeira do de dentro/de fora é o poder que a sua significação traz com ela, e o benefício que você recebe desta representação. Repare que quase nunca pensam que tem base em gênero. Eu ainda acho que gênero é um dos assuntos menos considerados de forma ampla - não que raça seja tratada - da nossa cultura. E se você estiver separando os de dentro e os de fora, então você está criando oposições, que na perspectiva Budista não é uma maneira habilidosa de fazer coisas. (2002)

Cocke do Roadside Theater explica a vantagem do status de estranho:

Quando viajamos, reconhecemos o valor de estar de fora das dinâmicas estabelecidas de uma comunidade. Isto porque, quando estamos em casa, gostamos de ter uma parte do nosso público como estrangeiros/ou de fora da nossa cultura e tradições. Por ser de fora eles fazem conexões além daquilo que nós vimos. Não gostamos quando todo mundo é de fora porque neste caso não há uma percepção do que seja a visão do de dentro; esta ressonância profunda com uma tradição, realmente a conhecendo, conhecendo a história da música e em que medida ela está sendo bem tocada. (2003b)

A performance baseada na comunidade às vezes acontece nos limites mais extremos da diferença, quando artistas com certo privilégio (raça, classe, educação ou circunstância) fazem arte com pessoas com quase nenhum poder. Suspeitamos daquela pessoa com uma situação confortável que quer fazer arte com pessoas que vivem na pobreza, algumas entrando e saindo de prisão, algumas tomando e parando de tomar drogas, outras incapazes de cuidar dos próprios filhos, e algumas crianças ainda tendo filhos? Nestas instâncias, 
este campo pode parecer como colonialismo. Constantemente, os artistas financeiramente mais estáveis, e pela maior parte brancos, traficam para o primeiro mundo os bolsões de pobreza entrincheirados no quarto-mundo. E o que é que os artistas fazem? - eles exploram o material cru, todas aquelas experiências e todas aquelas histórias. Depois partem com os recursos naturais e fazem deles a sua própria arte. É aqui que o modelo pára de funcionar; o mercado é localizado no primeiro mundo porque a arte não tem o poder de ajudar a construir a economia do quarto-mundo, o bastante para que ela possa servir como mercado. Neste sentido, a arte baseada na comunidade é pior do que colonialismo! Claro que os artistas podem também chegar e ficar na comunidade, fazendo uma encenação lá com o povo e os recursos locais. Eles podem ajudar a estabelecer um teatro naquela comunidade que continue depois que os artistas foram embora. Enquanto num primeiro momento os artistas podem ser ingênuos, a experiência pode ser um despertar social para as desigualdades e injustiças sociais do mundo. Os artistas podem reconhecer as suas próprias posições de poder e chegar a estimar a necessidade de parcerias igualitárias e o compartilhar de tomadas de decisões e de recursos.

Uma outra crítica da polaridade típica do de dentro/de fora em projetos de curto prazo baseados na comunidade é que parecem com o liberalismo - que significa que, diferente dos políticos radicais, o artista acredita que "o sistema" pode ser reformado. Este tipo de pensamento pode resultar em um processo de culpar a vítima, não reconhecendo que racismo e sexismo são institucionalizados e precisam ser desmantelados politicamente e socialmente; que estender a mão por meio do fazer artístico para pessoas que estão batalhando sem que se tenha uma proposta social mais ampla significa provavelmente uma atitude que terminará junto com o projeto. Os artistas que fazem este tipo de trabalho deveriam educar-se sobre as causas da injustiça e expandirem as suas estratégias baseadas em arte de acordo com pessoas que já o fizeram, ou para colaborar com estas pessoas. Isso implica na necessidade de desenvolver um modelo interdisciplinar de treinamento com um forte componente político para os artistas baseados na comunidade.

\section{Princípios}

Eu passo agora para os quatro princípios - contexto comum, reciprocidade, hifenação e cultura ativa - que sugerem boas razões para performance baseada na comunidade. Articulada em torno de preocupações comuns, a performance baseada na comunidade desafia a tendência para a profissionalização do engajamento cívico e de deixar especialistas lidarem com isso. Em um mundo de lobistas e política eleitoral baseada em democracia representativa e não participativa, a performance baseada na comunidade é um anacronismo bem-vindo. 
A performance baseada na comunidade surge de um contexto comum: o ofício e a visão do artista estão a serviço de um desejo específico do grupo. Este pode ser o de promover os objetivos do movimento de direitos civis, como no caso do Free Southern Theater. Pode também ser o de afirmar uma cultura sem representação ou mal representada, como no caso do Roadside Theater. Os artistas baseados na comunidade utilizam as suas ferramentas estéticas junto ao grupo de pessoas que tem experiência de vida sobre um assunto e com quem eles trabalham para moldar uma visão coletiva. A expressão comum é enraizada no reconhecimento de que muito da criatividade e do significado vem do grupo. O teatro, claro, já é uma arte colaborativa. A estrutura hierárquica da maioria dos teatros, porém, dá a maior parcela de poder ao produtor, ao dramaturgo, e ao diretor, enquanto a performance baseada na comunidade, pelo menos teoricamente, defende um modelo de poder compartilhado entre os vários artistas e parceiros da comunidade. Além disso, como no ritual, a arte baseada na comunidade recebe sentidos a partir de seu contexto; seus criadores são inspirados a fazer uma bela arte por causa do papel social significativo que ela exerce. A estética não tem uma importância menor no contexto ritual, mas neste caso eles estão apontando para um objetivo coletivo e não para o criador individual.

O apreciar do contexto coletivo do campo leva a uma reavaliação do gênio individual e coletivo. O primeiro é o bem conhecido e aceito modelo de arte do Ocidente. Dudley Cocke define o último como "a sabedoria acumulada de um povo, destilada e repassada pela tradição. Para tradições viverem, precisam ser renovadas regularmente. No teatro popular, o gênio individual, percebendo completamente a fonte coletiva dada a sua inspiração, esmaece a linha entre os dois" (2003c). Uma vez aceita a noção de gênio coletivo - uma realidade subjacente ao teatro, seja isso reconhecido ou não - a relação do artista com a comunidade é radicalmente modificada. Ao invés de ser uma pessoa alienada e sensível, o artista é alimentado pelas pessoas com as quais ele escolhe viver e trabalhar e pelo lugar onde escolhe estabelecer-se. Ele está engajado na vida compartilhada da sua comunidade. Por sua vez, apresenta a sua arte da maneira mais acessível, como com custo de ingresso baixo, locais acessíveis, e contextos convidativos.

Existem momentos, porém, quando o indivíduo está mais livre para apresentar pontos de vista contrastantes e heterogêneos ao coletivo. $\mathrm{O}$ indivíduo está livre para ser deslumbrante sem se preocupar em chocar o grupo. Além do mais, a dependência das tradições coletivas não é sempre possível. Como pensar sobre um grupo de atores ou espectadores heterogêneos que não compartilham uma tradição? E sobre as áreas ultrapassadas de uma tradição - por exemplo, os papéis de gênero cada vez 
mais delineados? Como alguém pode prevenir que uma tradição oprima, em vez de ser libertadora? Como é que o gênio coletivo pode enfrentar desafios contemporâneos sem o gênio individual?

A Inovação é essencial para o gênio coletivo - os artistas se permitem liberdade de experimentação e reinterpretação das tradições para seu tempo e espaço particular. Cocke acredita que o Roadside tem uma responsabilidade de fazer das tradições algo novo, reinventando-as para que se mantenham interessantes e instrutivas. Ele explica, "As pessoas que trabalham com a consciência de uma tradição, qualquer que seja, têm ainda mais incentivo para serem criativas do que os artistas que não são conscientes da tradição. Eles sabem o que já foi inventado, que é a mola propulsora para inventar algo diferente. Se não, você fica se debulhando sem ter um entendimento do caminho que a arte está trilhando, porque você não conhece os caminhos que ela já percorreu” (2003b).

As fontes dos gênios individuais e coletivos são interligadas. Liz Lerman descreve a flexibilidade necessária entre as duas: "Eu encontro muita inspiração, prazer, e desafios na minha colaboração com outros membros da companhia, outros artistas e membros de comunidades, exatamente como curto os momentos de saltos criativos. Seria bom se pudéssemos achar uma linguagem que apoiasse a idéia da visão artística fazendo um zig-zag entre gênio colaborativo e brilho individual” (2003a). Lerman nos estimula então a ultrapassar o pensamento isto ou aquilo e a necessidade de escolher entre gênio individual e coletivo.

A ênfase no gênio individual e exclusão de gênio coletivo pode desestimular pessoas não identificadas nessa categoria e fazê-las menos dispostas a participar de qualquer experiência artística. Estou perfeitamente satisfeita com a idéia de sentar-me de vez em quando e assistir a peças teatrais. Mas a idéia de gênio individual como o único modelo de produção de arte serve a uma perspectiva particular, não-democrática e ideológica. Está ligada a outros tipos de hierarquias e justifica que se dê mais aos julgados abençoados e talentosos do que aos outros membros da sociedade. Também serve à mercantilização total da arte; se só algumas pessoas selecionadas podem produzi-la, pode-se cobrar mais por ela.

O poder do contexto coletivo é utilizado para uma variedade de fins. Um exemplo especialmente agitador é a descrição da compositora/ativista Bemice Johnson Reagon de como, durante uma marcha, o som do canto dos que protestavam os precederam enquanto caminharam, "de forma que, até o momento que eles chegaram ao seu destino, as suas vozes já tinham ocupado 
o espaço de uma forma que não permitia que a polícia reclamasse. Não foi só a mensagem da música que foi importante, mas também a habilidade da música dar presença física e força visceral ao movimento" (Cieri e Peeps 2001, 271). $\mathrm{O}$ contexto coletivo conecta o lugar onde uma apresentação acontece, com quem será o público. A performance baseada na comunidade é habitualmente encenada em igrejas e escolas, em parques e centros comunitários, e de fato, em qualquer lugar onde se reúne o povo para o qual a apresentação é dirigida.

O próximo princípio, a reciprocidade, descreve a relação desejada entre artistas baseados na comunidade e os participantes como algo mutuamente nutritivo (mesmo que às vezes desafiador). Os participantes obtêm tais satisfações como a imagem e a imaginação, quer dizer, a tradução de idéias em formas, e o sonho sobre o que a vida poderia ser; a reflexão profunda, um resultado da construção da peça; a distância crítica nas suas vidas; e a visibilidade pública. Uma opinião constante das pessoas que participaram em tais projetos é de como se sentiram apreciados por estarem um momento sob o holofote e por serem tratados com respeito por pessoas interessadas nos seus pontos de vista.

Por meio da autoridade da sua experiência e a particularidade da sua imaginação, artistas tornam-se flexíveis ao aprenderem o que pessoas sabem e sentem. O diretor artístico de Cornerstone, Bill Rauch, descreve a experiência de ser preparado como um jovem diretor em Harvard para posteriormente tornar-se diretor artístico de um teatro profissional regional. Porém, ele estava decepcionado porque a maioria dos teatros regionais não eram, realmente, expressões de suas próprias regiões. Ele sabia que havia muitas histórias que nunca tinham sido ouvidas. De fato, o teatro profissional depende de agentes, submissões de roteiros, audições, e métodos de treinamento particulares que não são acessíveis a todo mundo que tem algo a expressar. Rauch acreditava que ele cresceria ao conhecer coisas que ele não sabia, de pessoas espalhadas pelo território Norte Americano, pessoas que tinham experiências diferentes das experiências dele. Com um grupo de colegas que tinham idéias similares, Rauch saiu na busca de um teatro que expressasse experiências tão ecléticas quanto a variedade do próprio país. A companhia Cornerstone, fundada por Rauch e seus colegas 1986, aproxima-se das pessoas tratando-as como parceiros no processo criativo; enquanto a Cornerstone garante a parte técnica, as pessoas, que vêem de circunstâncias bem variadas, oferecem o conteúdo.

A reciprocidade caracteriza o processo de arte baseado na comunidade. Os dançarinos/facilitadores de Urban Bush Women, inspirados em A People's History of the United States de Howard Zinn, entram nas comunidades convidando as pessoas a contarem histórias ainda pouco ouvidas. Eles 
chamam esse processo de juntar as histórias de "Quando os leões contam histórias” que, como sugere o provérbio africano, é muito diferente da versão do caçador (Zollar 2003). Em contraste aos especialistas de-cima-para-baixo que supõem o que seria de interesse para o povo, este processo usa as habilidades de artistas/facilitadores treinados para provocar e ajudar a um grupo variado de pessoas a expressar suas histórias.

O elemento central de reciprocidade na relação artista/comunidade é ouvir. Baseado em entrevistas extensas com pessoas que tiveram um envolvimento com o Cornerstone, Ferdinand Lewis escreve sobre o respeito, que toma forma concreta no saber ouvir: "O princípio de respeito refere-se a valorizar a contribuição da comunidade em todos assuntos, e apreciar as vidas e histórias dos parceiros e participantes comunitários de todas as formas possíveis. Na nossa experiência quando existe este fator nas decisões criativas e administrativas, é mais provável que os colaboradores contribuam de forma mais integral e verdadeira com o trabalho. $\mathrm{O}$ respeito cria as condições para que uma felicidade-em-criar essencial seja liberada, isto, por sua vez, envolve os colaboradores de maneiras extraordinárias" (2003a, 6).

Eu vivenciei este tipo de reciprocidade pela primeira vez em 1969, após conseguir meu primeiro trabalho como atriz profissional com o Players' Theatre de Manchester, em New Hampshire. Graças a uma bolsa, pela qual o governo federal equiparou os orçamentos locais, nós estávamos apresentando uma peça baseada em Daniel Webster de New Hampshire, nas pequenas cidades da região das White Mountains, da Nova Inglaterra. As pessoas dessas cidades queriam nos contratar, mas não saberiam dizer quanto de dinheiro poderiam nos pagar até a noite da nossa apresentação, pois pretendiam angariar o dinheiro promovendo um jantar de arrecadação antes do espetáculo. O que eles nos prometiam era um jantar caseiro. Nós aceitamos estas condições e chegamos na câmera municipal em uma atmosfera de grande animação. Quase todos os espectadores tinham feito um prato delicioso, estabelecendo uma sensação de reciprocidade como eu raramente tinha experimentado em qualquer outro evento. Este espírito contaminou a própria apresentação do espetáculo, contando tanto com a generosidade extra dos atores, como com a receptividade extra dos espectadores. Isto era um resultado da criação mútua dos prazeres daquela noite.

Em contraste, o teatro comercial como instituição carrega um aparato inteiro de hierarquia. Aqueles capazes de angariar mais fundos estão no topo, sejam eles os produtores ou as estrelas. O dramaturgo geralmente é o segundo, demonstrando a inclinação da civilização ocidental em favor da expressão escrita acima da oral e física. A seguir vem o diretor, e depois o resto do "time criativo"- designers, compositores e coreógrafos. Depois os atores meramente 
intérpretes, seguidos pelo mais abaixo ainda os técnicos, simples trabalhadores qualificados. Por fim e por último, quando chega a ser discutido, está o público. Alguns anos depois da minha experiência em New Hampshire, ao apresentar em uma sala experimental "fora do circuito da cidade" (ou seja, fora de Nova Iorque), eu tinha a terrível sensação de que não tinha ninguém na platéia. Não eram as luzes brilhantes do palco e o auditório no escuro - um espetáculo com base na comunidade pode escolher este desenho de luz para apoiar o foco. Concebido mais como um teste fora da cidade, a apresentação não era para os espectadores verdadeiros e sim uma preparação para se apresentar em outros lugares. De uma forma profunda, o público para o qual estávamos apresentando não estava lá.

Aplicar o critério de reciprocidade alivia várias concepções errôneas. Por exemplo, a arte baseada na comunidade contrasta distintamente com "serviço comunitário" que traz a idéia de um sopão, com os bem alimentados de um lado servindo sopa para os famintos que recebem do outro lado. Este modelo unidirecional não é recíproco; não apóia trocas significativas. Nem esse campo é uma celebração monolítica do que é comum entre os humanos, apagando as diferenças muito reais que podem existir entre artistas e parceiros locais. A Reciprocidade depende de diálogo, que se refere a "duas ou mais partes com pontos de vista diferentes trabalhando para conseguir um entendimento comum em uma discussão aberta e cara a cara" (Bacon et al 1999, 12). Os artistas têm que estar tão sensíveis às suas diferenças em relação aos participantes quanto à base comum que compartilham. Todos os envolvidos precisam apreciar verdadeiramente o que os outros dão como colaboração, se não for desta maneira, por que fazer?

Baseado em sua teoria de heteroglossia, o teórico literário russo Mikhail Bakhtin refere-se ao dialogismo como o modo quintessencial de saber. No coração desta idéia complexa está a primazia do texto em relação ao contexto: "uma palavra proferida num lugar particular num momento particular significa algo diferente do que significaria em qualquer outra circunstância” (Bakhtin 1981, 428). Dialogismo, para Bakhtin, significa que tudo tem de ser entendido como parte de um todo maior. Existe uma interação constante entre significados, todos os quais têm o potencial de condicionar outros significados (426-427). Bakhtin vê o objetivo do diálogo não como uma solução específica, mas como um co-entendimento. Ele também teoriza sobre os nossos próprios diálogos internos na distinção que ele faz entre discursos autoritários e discursos internamente persuasivos (341-342). O anterior refere à voz do pai, do estado, a autoridade externa imposta de fora do ser. $\mathrm{O}$ posterior refere-se a nossa própria autoridade internalizada, conseguida por uma síntese das vozes internas e externas. 
A reciprocidade é refletida na posse conjunta do trabalho criado pela comunidade local e pelo artista/facilitador. Às vezes há o perigo dos artistas imporem a sua própria estética e ideologia. No entanto é necessário precaução quanto a acusações de artistas “usarem” uma comunidade. Suzanne Lacy mantém rédeas curtas nos desfiles e paradas que ela cria com centenas de pessoas. Eu vejo isso como uma escolha metodológica, não como uma imposição. Dentro do processo de Lacy, as pessoas têm muitas oportunidades de explorar os seus assuntos, criar laços com outras pessoas, e se tornarem mais públicas. Os artistas podem da mesma forma ser pouco envolvidos, aparentemente não-comprometidos, o que pode resultar em um trabalho que contradiz suas próprias posições políticas. Uma peça pode representar a todos os envolvidos exceto o artista facilitador e arriscar assim cair em um modelo unidirecional, o artista-ajudando-o-povo. A posse [autoral] coletiva é um outro desafio que às vezes os artistas estão mais preparados para a mudança do que a comunidade. Linda Parris-Bailey de Carpetbag Theater descreve a necessidade do bom senso uma vez que a comunidade dela não é tão ativa: “Às vezes a comunidade é desafiada e precisa ser desafiada, e às vezes não gostam disso. Mas isto faz parte da maneira que nós todos crescemos. Então não temos que agradar constantemente" (Watkins 2002b).

A Reciprocidade é enraizada em um modelo de construção comunitária que "insiste em começar com um compromisso claro de descobrir as capacidades e recursos de uma comunidade”(Kretzman e McKnight 1993, 1). Este modelo contrasta-se com aquele que foca nas deficiências e nos problemas de uma comunidade. Na performance baseada na comunidade, tanto os artistas como os organizadores precisam encontrar os pontos fortes da comunidade. Os organizadores comunitários John P. Kretzman e John L. McKnight explicam que enquanto as comunidades pobres têm problemas, enfatizar exclusivamente os aspectos negativos resulta em (1) residentes daqueles bairros pensando nas deficiências como a realidade única; (2) tentativas fragmentadas de amenizar a situação quando, na realidade os problemas geralmente são interligados; (3) repasse de verbas para pessoas que oferecem serviços e não para os residentes; e (4) a percepção de que só as pessoas de fora podem ajudar. Os autores concluem que "o desenvolvimento comunitário significativo acontece só quando pessoas locais da comunidade têm compromisso em envolver-se e em investir seus recursos neste esforço" (5). Estes critérios aplicam-se às parcerias entre artistas da mesma companhia, entre duas companhias, e com participantes da comunidade, tanto indivíduos como instituições.

Ron Short do Roadside Theater expressa a satisfação pessoal resultante de um terceiro princípio da performance baseada na comunidade, é o que eu chamo de hifenação: "Porque eu não iria querer fazer este trabalho? É tão central 
a quem eu sou. É ritual e religião para mim. É a integração da minha história, da minha cultura e da minha família” (Fields 2002a). O diretor artístico de Jump-Start Steve Bailey diz: "Relaciona à criação de um intercâmbio com a comunidade, que não acontece somente por meio de trabalho com teatro" (Hennessey 2002). A performance baseada na comunidade é hifenada por consistir tanto de disciplinas múltiplas (estética e algo mais como educação, construção de comunidade, ou terapia) e funções múltiplas, tendo como objetivos a eficácia e o entretenimento.

A noção de hifenação trás à memória a observação de Schechner de que qualquer performance específica pode ser vista em um continuum entre a eficácia e o entretenimento $(1977,75)$. Quanto mais as suas características caem no primeiro termo, mais próxima ao ritual fica a performance, e quanto mais suas características caem no termo posterior, mais a performance é teatro. De fato, uma única performance encenada em dois contextos diferentes poderia ser caracterizada diferentemente. Uma performance da dança da chuva, por exemplo, é teatro, não ritual, quando apresentado para um público de turistas. Mas feita por e para pessoas com o objetivo de trazer chuva, e dentro do sistema espiritual ao qual aderem, é ritual.

De outra forma uma produção teatral pode virar ritual dependendo do contexto. Assim foi a minha experiência em uma produção de Palsettoland na Broadway, no início da década de noventa. Quando o protagonista da peça lamentava a perda do seu amigo por causa da AIDS, eu chorava pela perda do meu querido amigo David e sem perceber esbarrei em um estranho ao meu lado. Ele, chorando com uma liberdade que também pareceu transcender a morte da personagem, encostou-se em mim também, comunicando uma grande empatia. Em todo lugar eu vi espectadores chorando e senti que o evento teatral foi um grande funeral público para nossos entes amados mortos pela AIDS. A força de atração na performance baseada na comunidade é normalmente consistente de ambos os lados do continuum ritual/eficácia e arte/entretenimento.

Os artistas experimentam com freqüência a arte em relação a algo adicional à estética, como a religião, terapia, educação, ou a articulação e expressão de um ponto de vista ou visão política. A performance baseada na comunidade é ainda mais intrinsecamente hifenada. O poeta Muriel Rukeyser (1974, 23-24) expressa a diferença entre arte sobre algo e arte que faz algo: "Porque você imaginou amor, você não amou; meramente porque você imaginou irmandade, você não fez irmandade.” Para os praticantes nesta área, a expressão simbólica não basta; eles/elas querem que a sua arte tenha algum impacto social concreto, e querem uma vida na arte que interaja com outros 
territórios (como a terapia ou a organização comunitária). Então a performance baseada na comunidade desafia a estética tradicional que, segundo o American Heritage Dictionaryé "uma doutrina pela qual a arte e artistas são considerados livres de qualquer obrigação ou responsabilidade fora da busca da beleza” A concretude que Rukeyser evoca posiciona novamente este campo entre a arte e o ritual, entre o entretenimento e a eficácia.

Para a artista baseada na comunidade Susan Ingalls, o objetivo geral do seu trabalho não é fazer uma arte superior a qualquer custo, mas dar aos participantes uma "experiência positiva fundamental." Esta é uma aventura que abre uma noção expandida do ser e do que o ser é capaz, e com ela, uma sensação de preenchimento. A experiência positiva fundamental pode ser o resultado de uma experiência emocional, intelectual, física, ou estética: uma viagem a Outward Bound desafiadora ou um esporte de equipes tanto quanto um esforço de produção artística. No mesmo espírito, o conceito de Ingalls (1996) de "testemunha simpática”, o artista/facilitador que reforça o membro da comunidade como princípio do seu trabalho, tem sentido em um campo que não é preocupado somente com a estética.

Como um campo hifenado, a performance baseada na comunidade se fundamenta em outras disciplinas além do teatro. Ingalls expandiu a sua prática artística para servir a objetivos sociais influenciados por Teacher, o relato de Sylvia Ashton-Warner sobre a instrução de crianças Aborígenes na Austrália, começando com "palavras chaves" que as crianças geram que são significativas para elas. Ingalls adaptou a prática de Ashton-Warner em uma abordagem que ela chama de "Palavras Funcionam" ["Words Work"] e conseguiu despertar o interesse de crianças na leitura, começando com as suas próprias palavras chaves antes de avançar para textos.

Muitos artistas baseados na comunidade buscaram inspiração no brasileiro Paulo Freire, cuja pedagogia libertária propõe uma teoria e um método para alfabetizar, especialmente para adultos. $\mathrm{O}$ alcance de Freire supera o reconhecimento de palavras e chega ao reconhecimento mais profundo, um aprendizado de leitura do mundo: "Cada ser humano, não importa quão 'ignorante’ ou submerso na 'cultura de silêncio,' é capaz de olhar criticamente o seu mundo num diálogo de encontro com outros, e se oferecermos as ferramentas certas para tal encontro ele pode gradualmente perceber a sua realidade pessoal e social e lidar criticamente com ela" (Freire 1970, capa).

O companheiro brasileiro Augusto Boal integrou princípios centrais da "pedagogia do oprimido" ao seu "teatro do oprimido". Por exemplo, Freire pediu o fim do modelo de educação bancária, dentro do qual os estudantes são 
tratados como recipientes passivos, objetos, dentro do qual o professor deposita o seu conhecimento. No lugar disto, Freire propôs um método dialógico de educação, onde todos são sujeitos. Similarmente, Boal substituiu o espectador, o receptor passivo dos critérios do artista, com o especta-ator, que é capaz de intervir e substituir o ator/protagonista por meio de uma série de técnicas que dinamizam o espectador de outrora em um sujeito ativo.

Como etnografia, a arte baseada na comunidade é uma colaboração entre artistas profissionais e pessoas de todo tipo, centrada na expressão de comportamento e prática humana significativos. O antropólogo James Clifford define etnografia como "maneiras diversas de pensar e escrever sobre a cultura do ponto de vista da observação participante” (9). Segundo esta definição, os artistas baseados na comunidade também são etnógrafos. De fato, o trabalho de campo, a prática de pesquisa antropológica, baseada na observação participante, pode ser tão valorizada pelos artistas baseados na comunidade quanto para os antropólogos: "para poder entender e apreciar completamente as ações da perspectiva dos participantes, deve-se aproximar e participar, de um modo amplo e variado, das atividades do dia-a-dia deles, ao longo de um período de tempo" (Emerson, Fretz, e Shaw 1995,10).

O princípio de cultura ativa reflete o reconhecimento de que as pessoas normalmente têm mais retorno por fazer arte do que por ver os frutos do trabalho de outros. Tais experiências motivam pessoas a minar dos seus corações e das suas mentes experiências e concepções. A cultura ativa é refletida também em um outro axioma central da área - que todo mundo tem potencial artístico. Achar os pontos fortes estéticos de cada ator iniciante é um dos desafios maiores para artistas baseados na comunidade. Bill Rauch é um mestre na seleção de elenco para papéis que são enriquecidos pela experiência pessoal do ator. Assistir ao chefe da tribo Walker River Paiute fazer o papel do rei em The House on Walker River, adaptação da Orestéia de Ésquilo, incrementou de tal maneira a performance que mais do que compensou a falta de treinamento teatral do ator. Em outras palavras, como o campo se baseia em disciplinas múltiplas, pode também aproveitar das múltiplas capacidades das pessoas e aplicá-las na performance.

Liz Lerman vê seu papel como o de "manter-se aberta para ver a beleza do que pessoas, sem treinamento nas artes, fazem e fazer isso funcionar." Lerman distingue entre o "processo criativo" e o "fazer artístico" O primeiro é a livre exploração de temas, na medida em que o artista tenta fazer pessoas sentirem-se relaxadas e confiantes e encorajar o fluxo de material. A segunda fase é a edição e a formatação do material em algo que pode ser articulado para um público que não participou do processo criativo. Alguns projetos 
comunitários ficam na primeira fase. Lerman está interessada no como trazer os grupos para a segunda fase. Ela nota uma falácia na idéia de que somente na arte comunitária os artistas se preocupam em não ferir os sentimentos dos participantes no processo de edição. Ao contrário, ela percebe ser este um processo delicado também companhias profissionais com projetos de criação coletivas. Nos dois casos, o diretor/coreógrafo lida com lealdades conflitantes - à obra de arte, aos participantes, ao público. Lerman (1997) acredita que os artistas precisam ser duros sem serem cruéis, usar suas habilidades de edição sem serem desnecessariamente autoritários.

A inclusão e a diversidade são dois outros elementos de cultura ativa. Na "Matriz de Princípios de Teatro de Base/Popular," esta idéia é categorizada de duas maneiras. Primeiro, "A inclusão é um valor central expresso por meio de preços de ingressos mais em conta, locais acessíveis, e parcerias com organizações da comunidade.” A segunda é mais explicitamente sobre a relação de justiça social: "O teatro de base é ligado às lutas para igualdade cultural, social, econômica e política para todos”(Cocke et al 1993, 81). Cornerstone analisa a diversidade como um dos seus quatro princípios centrais na colaboração comunitária (os outros três são a escuta, o respeito, e a flexibilidade). Ferdinand Lewis escreve sobre o Cornerstone:

A experiência tem mostrado que nenhuma comunidade é tão monolítica que não contenha uma grande mescla de diversidade...Como estrutura para a criatividade, o conceito de diversidade pode liberar a imaginação de idéias monolíticas, e estimular colaborações inesperadas... [Q]uando possivel, a equipe de montagem deveria representar uma diversidade de experiências com colaborações do Cornerstone, incluindo aqueles participantes que poderiam estar fazendo o seu primeiro projeto junto com os que já colaboraram com a companhia no passado”. (2003a, 6)

Para o Cornerstone, então, a cultura ativa, expressa como inclusão e diversidade, é ao mesmo tempo um pilar estético e filosófico do trabalho.

As quatro características de contex to comum, reciprocidade, hifenação, e cultura ativa se reforçam mutuamente. Ter raízes em um contexto comum é possibilitado por uma interação profunda e recíproca com as pessoas que se identificam com aquele contexto. Expandir a participação - isto é, a cultura ativa que leva para a performance hifenada - não-artistas trazem outras fontes de conhecimento. Com a arte de um lado do hífen, o "algo mais" no outro lado pode também formar o desenvolvimento de um projeto. A natureza daquela performance, para servir ao máximo aquelas pessoas, é capaz de fazer algo 
além de ser algo, de ter objetivos de eficácia, assim como estéticos. Que o processo de criação seja o mais ativo e inclusivo possível é tão importante quanto a produção final. A performance baseada na comunidade significa tanto construir a comunidade quanto expressar a comunidade.

\section{A performance baseada na comunidade como processo}

Os artistas baseados na comunidade podem lutar para incorporar os valores, alcançar os objetivos, e se integrarem com os grupos porque este tipo de performance não é somente a apresentação, mas todos os processos anteriores e posteriores à apresentação. O tempo se abre; este trabalho é sobre muito mais do que a transação entre atores e espectadores no período curto da apresentação, por mais poderosa que esta seja. Como no teatro experimental de forma geral, a performance baseada na comunidade é distinta por realçar o processo. Boal explica porque os teatros populares tendem a enfatizar o que está em processo e incompleto: "A burguesia já sabe como é o mundo, o seu mundo, e pode, portanto, apresentar imagens desse mundo completo, terminado. $\mathrm{O}$ proletariado e as classes exploradas, ao contrário, não sabem ainda como será o seu mundo; conseqüentemente, o seu teatro será o ensaio” (1991, 164).

Os critérios de Boal sobre processo no teatro nos remetem ao grande filósofo político Frederick Engels, que explica:

O grande pensamento básico que o mundo não é para ser compreendido como um complexo de coisas já-feitas, mas como um complexo de processos, no qual as coisas aparentemente não menos estáveis do que as suas imagens-mentais nas nossas cabeças, os conceitos, passam por uma mudança ininterrupta de chegar a ser e morrer, na qual, apesar de todos os acidentes aparentes e de toda regressão temporária, um desenvolvimento progressivo se afirma no final - este grande pensamento fundamental tem, desde os tempos de Hegel, tão completamente permeado a consciência ordinária que nesta generalidade é quase nunca contradito. (Selsam e Martel 1963, 100-101)

A ênfase no processo cria espaços para interação e, talvez mais importante, a base para acreditar na mudança, seja pessoal ou política. $\mathrm{O}$ valor igual atribuído às fases pré e pós-apresentação - a peça, em e por si mesma, não é a (única) coisa - corresponde à estrutura de ritos de passagem, aquela categoria de ritual que propicia um processo não só para os indivíduos passarem por mudanças, mas para a sua comunidade reconhecer e adaptar-se a mudança. Como nos rituais, as performances baseadas na comunidade são processos estruturados capazes de conduzir as pessoas pelas mudanças. 
Segundo o antropólogo Arnold can Gennep (1960), os ritos de passagem têm estruturas de três partes: separação, liminaridade, e reintegração. Na primeira fase, as pessoas passando pela mudança são tiradas da sua vida cotidiana para serem preparadas especialmente para a mudança. A fase média é um período intermediário, durante o qual os participantes não estão mais na categoria antiga, mas ainda não estão na categoria nova. A terceira fase, freqüentemente marcada por uma performance, é o momento de reincorporar a pessoa de volta à comunidade com o novo status. Um exemplo de um rito de passagem é o casamento. A fase de separação corresponde ao período de compromisso crescente durante o qual o casal para de flertar com outras pessoas. Na fase de "noivado" o casal fica no meio - não são mais solteiros, mas ainda não são casados. $\mathrm{O}$ casamento marca o novo status do casal na comunidade como casados, não só para eles mesmos, mas também para pais e amigos, com a mudança de comportamento que deveriam exibir também.

Richard Schechner $(1985,21)$ identifica sete fases possíveis para qualquer apresentação, em um “padrão análogo a ritos de iniciação" e referindo-se a van Gennep. As primeiras quatro fases de Schechner treinamento, oficina, ensaio, e aquecimento - correspondem à primeira fase ritual de van Gennep, a “separação.” São processos pelos quais os atores passam antes de ter contato com o público, e durante os quais eles preparamse para a apresentação. A fase do meio do um rito de passagem, a liminaridade, corresponde à quinta fase de Schechner, à apresentação, durante a qual a transformação é representada simbolicamente, mas ainda não efetuada na vida cotidiana. A noção de reintegração de van Gennep, o ponto no qual as pessoas que passaram pelo rito de passagem se reúnem com a sua sociedade com novos papéis e responsabilidades, corresponde às últimas duas fases de Schechner, relaxamento e resultado. Estas fases garantem oportunidades para experimentar os princípios da performance baseada na comunidade - o contexto comum, a reciprocidade, a hifenação, e a cultura ativa.

A primeira fase é treinamento. Dada a natureza hifenada deste campo, é necessário aprender habilidades múltiplas junto com as artísticas. Dudley Cocke, por exemplo, enfatiza a necessidade de artistas de base aprenderem organização comunitária. Escritora baseada na comunidade Alice Lovelace, ela acredita que artistas trabalhando para mudança social precisam de treinamento na resolução de conflitos. Habilidades particulares relacionadas à performance também são valorizadas. $\mathrm{O}$ ator/diretor Mark McKenna reflete sobre a escola de Dell'Arte, que ensina técnicas de teatros populares como a commedia, um modo inerentemente interativo: "Estudantes chegam a entender a responsabilidade do performer em relação ao público” (2002). O foco da escola está em criar o seu próprio trabalho, uma habilidade crítica para os atores baseados na 
comunidade. A Dell'Arte ensina uma percepção do artista como sendo o dono do seu trabalho; Steve Bisher diretor associado da escola diz que antes de fazer oficinas com Michael Fields, também da companhia, ele "não sabia que como ator você poderia ter os seu próprios pensamentos”(McKenna 2002).

A próxima fase, oficina, é um período para construir a performance. Incorpora input comum de uma forma ou de outra. Tanto as pesquisas primárias como as secundárias geram material para criar o espetáculo. Histórias são colhidas, o assunto em questão é investigado, e um roteiro é desenvolvido em um processo envolvendo artistas e normalmente participantes da comunidade. A estrutura de tal participação varia. Por exemplo, cada apresentação comunitária de Cornerstone incorpora uma média de vinte encontros com grupos e líderes principais e locais. A companhia começa por achar uma pessoa local “apostando na fé", e tornam esta pessoa um defensor do projeto, ajudando a achar pessoas apropriadas para um comitê de conselheiros. Cornerstone diz para o comitê como é que deveriam construir um projeto, e o comitê aconselha como fazer esta construção naquele lugar. A inclusão da fase de oficina impacta quem vem para o espetáculo. O membro da platéia de Dell'Arte, Kit Zettler dá um exemplo: "Você não vai necessariamente conseguir um madeireiro que venha assistir a esta peça e saia dizendo que ele nunca mais vai fazer isso. Mas um madeireiro vem para a peça porque um amigo dele foi entrevistado ou alguém conversou com ele” (McKenna 2002). Então ele acaba escutando outros pontos de vista.

Uma variação na fase de oficina é o que Suzanne Lacy (2003) chama de imersão, que focaliza a organização de habilidades de organização e também estéticas. Em uma etapa anterior no processo, Lacy treina participantes para contextualizar o trabalho em organizações comunitárias e na mídia. Por exemplo, em Code 33, Lacy mandou que saíssem a campo participantes adolescentes para conversar com repórteres e políticos sobre o policiamento na comunidade, ainda enquanto elaboravam o espetáculo. Criar o fundamento para os componentes públicos de Code 33 aconteceu em paralelo ao trabalho nos seus componentes estéticos internos.

Durante o processo de ensaio, nos projetos integrando atores iniciantes, as habilidades do artista têm que ser adaptadas às pessoas com quem irão trabalhar. Percebendo o que um elenco não-treinado é capaz de repetir, o diretor precisa fazer escolhas para realçar as forças e amenizar as fraquezas dos atores. Alguns conjuntos, como Cornerstone, incorporam música, dança, e espetáculo para intensificar a experiência estética. Os membros profissionais do elenco são responsáveis não só por eles mesmos, mas também pelo elenco comunitário, com freqüência ensaiando várias cenas pequenas simultaneamente 
para otimizar um tempo que nunca é o suficiente. Quando ensaiando com um elenco completamente profissional, a performance baseada na comunidade se assemelha com qualquer outra produção de grupo. Companhias como Dell'Arte têm uma estética estabelecida, que só pode ser realizada por pessoas com anos de treinamento. A repetição da fase de ensaio também funciona como ritual por ligar membros do elenco que de outra forma nunca teriam se encontrado, se conectado ou interagido.

Ambas as fases de oficina e ensaio dependem do que muitos facilitadores chamam de "espaço seguro." Baseado no valor de inclusão, como é que tais artistas criam ambientes, utilizando habilidades além do fazer artístico, onde as pessoas realmente podem participar? Como é que facilitadores mantêm uma atmosfera livre e aberta sem permitir interações prejudiciais entre pessoas acerca de suas diferenças? Como é que diretores identificam um papel que uma pessoa vai exceder sem escolher pelo tipo físico dele ou dela? Como é que artistas baseados na comunidade podem reforçar valores como diversidade sem ficarem autoritários, especialmente quando valores contrários podem estar fundidos com outras partes das vidas dos participantes?

Aquecimento é o processo que imediatamente precede a apresentação. Em peças planejadas para otimizar a participação do público, é normalmente dada aos espectadores uma forma de se preparar também, talvez por meio de exercícios físicos ou vocais. O jantar de arrecadação da comunidade é um outro formato popular. Cocke conta que "com freqüência os atores de Roadside passam diretamente do encontro social ao palco e começam o espetáculo” tendo assim estabelecido uma conexão.

Em seguida, a própria performance oferece maneiras dinâmicas para a troca ator-espectador e ilustra a hifenação da área. Red Summer do Carpetbag Theater foi baseado na documentação histórica sobre ativistas de Knoxville, durante a era de direitos civis. A diretora Linda Parris-Bailey viu Red Summer como uma maneira de dizer para os residentes que a crença de que nada poderia mudar era historicamente incorreta: "Talvez, se simplesmente pudermos lembrá-los do que existia antes aqui, vocês possam ver algumas possibilidades para o futuro. Falamos de pessoas que assumem o controle" (Watkins 2002b). Parris-Bailey também enxerga um componente fundamentalmente celebratório nas peças históricas da companhia. E é uma satisfação para os atores e o público devolver para as comunidades histórias originárias dali. Uma outra função do espetáculo é a crítica pública. O texto de Agents and Assets do LAPD é a transcrição de uma audiência do congresso sobre o envolvimento da CIA na venda de cocaína na Califórnia. É uma crítica à Guerra contra Drogas. LAPD é composto principalmente de pessoas sem- 
teto. Existe uma ironia quando se escuta as palavras de políticos educados e habilidosos faladas por atores que em algum momento foram vítimas da guerra contra drogas. Ter um ator do LAPD retratando um político cria uma crítica embutida. The Embrace do Pregones é um exemplo de uma produção que integra o diálogo do público. Utilizando o teatro-fórum de Boal, os espectadores são convidados a substituir um protagonista na luta sobre uma questão social, neste caso como um resultado de se estar com AIDS. Os espectadores encenam diferentes maneiras possíveis de lidar com estas lutas, como parte do espetáculo, entrelaçado com diálogo.

A fase de relaxamento segue imediatamente após o espetáculo e pode tomar a forma de uma discussão. Apesar de serem freqüentemente efetivas, as discussões não são sempre o mais desejado. Às vezes os espectadores não estão prontos para conversar sobre um espetáculo tão rapidamente; às vezes os artistas trazem líderes para a discussão, mas o público só quer ouvir do artista. O Pregones geralmente poupa a discussão para obras novas que eles pedem para o público avaliar. As histórias que pessoas contam nas rodas de histórias seguindo as apresentações de Roadside garantem um tipo de crítica, ajudando o conjunto a sentir se fizeram um trabalho efetivo ou não. Um outro local de reciprocidade são os painéis pós-espetáculo, que podem ser tão valiosos para participantes especialistas como para os artistas. No Agents and Assets, especialistas sobre a CIA em um painel relataram ser educados por co-participantes de Skid Row. Em um outro exemplo, o Cornerstone, em uma colaboração com Touchstone Theater, arranjou encontros pós-espetáculo com sobremesas e drinques para que espectadores pudessem ter conversas não mediadas uns com os outros. Os artistas de Alternate ROOTS habitualmente usam o Processo de Resposta Crítica desenvolvida pela coreógrafa Liz Lerman, depois de mostrarem um trabalho ainda em construção. Lerman desenvolveu este processo para por o próprio artista em controle da sessão de comentários.

Resultados/atividades de longo-prazo seguindo o espetáculo, mas não imediatamente, levam a iniciativa ainda mais além. Porque um dos mantras deste campo é a sustentabilidade: artistas têm que deixar algo para trás. No final do dia, depois do fim da apresentação, há pessoas locais com habilidades para facilitar outros trabalhos? Existe uma rede de apoio, qualquer tipo de programa contínuo para pessoas cujos apetites não foram satisfeitos?

Os resultados são a etapa seguinte à apresentação, durante a qual espectadores, possivelmente facilitados pelos artistas, atuam sobre novas percepções. Os exemplos de resultados são ecléticos. Durantes os anos nos quais o Cornerstone fez residências em cidades pequenas por todos os 
Estados Unidos, eles doaram dinheiro para cada cidade iniciar um teatro. LAPD fez uma parceria com uma organização chamada SRO (Single-Room Occupancy) Housing, que, até 2002, tinha reformado trinta cortiços que foram transformados em hotéis para a ocupação de quartos individuais. (Lewis 2002b). De forma geral eles compartilham a missão de ajudar pessoas a deixar as ruas. LAPD adiciona uma dimensão criativa ao SRO, que por sua vez providencia uma infra-estrutura que alimenta o LAPD. Às vezes assistir a uma performance baseada na comunidade influencia uma decisão posterior de se envolver ativamente na vida política/cívica. Como o conceito de Ingall, da experiência chave-positiva, às vezes leva anos para as pessoas perceberem que tiveram uma experiência transformadora por meio da arte, ou, em termos rituais, que passaram por um rito de passagem que efetuou uma mudança permanente.

\section{Referências Bibliográficas}

Bacon, Barbara Schaffer, Cheryl Yuen, e Pam Korza. 1999. Animating Democracy: The Artistic Imagination as a Force in Civic Dialogue. http://www.artsusa.org.

Bakhtin, Mikhail. 1981. The Dialogic Imagination. Trad. Caryl Emerson e Michael Holquist. Austin: University of Texas Press.

Becker, Carol. 1994. "Herbert Marcuse and the Subversive Potential of Art." Em The Subversive Imagination, 113-129. New York: Routledge.

Berger, Maurice, ed. 1998. The Crisis of Criticism. New York: New Press.

Boal, Augusto. 1979. Theatre of the Oppressed. Trad. Charles A. e Maria-Odilia Leal McBride. New York: Urizen.

Broyles-Gonzalez, Yolanda. 1994. El Teatro Campesino. Austin: University of Texas Press.

Burnham, Linda. 2003. Personal correspondence with the author via email. 15 Junho. Cieri, Marie, e Claire Peeps, eds. 2001. Activists Speak Out: Reflections on the Pursuit of Change in America. New York: Palgrave.

Clifford, James. The Predicament of Culture. Cambridge: Harvard University Press. Cocke, Dudley. 2003a. "A Call to Experimentation.” Keynote speech. Amherst College, Network of Ensemble Theaters Festival, 23 Julho.

. 2003b. Personal correspondence with author. 20 Julho.

Cocke, Dudley, Harry Newman, e Janet Salmons-Rue, eds. 1993. From the Ground Up: Grassroots Theater in Historical and Contemporary Perspective. Ithaca, NY: Cornell University.

Emerson, Robert M., Rachel I. Fretz, e Linda L. Shaw. 1995. Writing Ethnographic Fieldnotes. Chicago: University of Chicago Press. 
Fields, Michael. 2002. "Interviews with Roadside Theater." Performing Communities, ed. Robert H. Leonard, Ann Kilkelly, Linda Burnham, e Steve Durland. http://www.communityarts.net.

Freire, Paulo. 1970. Pedagogy of the Oppressed. New York: Continuum.

Gennep, Arnold van. 1960. The Rites of Passage. Trad. Monika B. Vizedom e Gabrielle L. Caffee. London: Routledge and Keegan Paul.

Gornick, Vivian. 2001. The Situation and the Story. New York: Farrar, Straus and Giroux.

Guinier, Lani, e Gerald Torres. 2002. The Miner's Canary. Cambridge: Harvard University Press.

Hall, Stuart. 1965. The Popular Arts. New York: Pantheon.

Heath, Stephen, e Gillian Skirrow. 1986. "An Interview with Raymond Williams." Em Studies in Entertainment, ed. Tania Modlewski, 3-17. Bloomington: Indiana University Press.

Hennessey, Keith. 2002. "Researcher, Jump-Start Theater." Performing Communities, ed. Robert H. Leonard, Ann Kilkelly, Linda Burnham, e Steve Durland. http://www.communityarts.net.

Ingalls, Susan. 1996. "The Six Concepts of Community-Based Education." Unpublished Manuscript. Children and the Classics, New York.

Kretzman, John P., e John L. McKnight. 1993. Building Communities from the Inside Out. Chicago: ACTA Publications.

Lacy, Suzanne. 2002. Interview by author. 23 Maio. Oakland CA. 2003. Interview by author. September 20. Los Angeles.

Lerman, Liz. 1997. Telephone interview by author. 28 Junho. 2003a. "Dancing in Community: Its Roots in Art." http://www. communityarts.net/readingroom/archive/intro-dance.php. . 2003b. Interview by author. 2 Outubro. Princeton University.

Lerman, Liz, e John Bortsel. 2003. Critical Response Process. Takoma Park, MD: Liz Lerman Dance Exchange.

Levine, Lawrence. 1988. Highbrow/Lowbrow. Cambridge: Harvard University Press. Lewis, Ferdinand. 2002. "Researcher, Los Angeles Poverty Department (LAPD).” Performing Communities, ed. Robert H. Leonard, Ann Kilkelly, Linda Burnham, e Steve Durland. http://www.communityarts.net. ed. 2003. Cornerstone Community Collaboration Handbook. Los Angeles: Author. MacAloon, John J., ed. 1984. "Introduction: Cultural Performances, Cultural Theory.” Em Rite, Drama, Festival, Spectacle: Rehearsals Toward a Theory of Cultural Performance, 1-15. Philadelphia: Ishi. 
McKenna, Mark. 2002. "Researcher, Dell'Arte Players." PerformingCommunities, ed. Robert Leonard, Ann Kilkelly, Linda Burnham, e Steve Durland. http:// www.communityarts.net.

Myerhoff, Barbara. 1978. Number Our Days. New York: Simon and Schuster.

Rukeyser, Muriel. 1974. The Life of Poetry. New York: Morrow.

Schechner, Richard.1973. Environmental Theater. New York: Hawthorne Books.

--. 1977. Essays on Performance Theory, 1970-1976. New York: Drama Book Specialists.

--. 1985. Between Theater and Anthropology. Philadelphia: University of Pennsylvania Press.

Schechner, Richard, e Willa Appel, eds. 1980. By Means of Performance. New York: Cambridge University Press.

Selsam, Howard, e Harry Martel, eds. 1963. Reader in Marxist Philosophy: From the Writings of Marx, Engels and Lenin. New York: International Publishers Co. Strinati, Dominic. 1995. An Introduction to Theories of Popular Culture. London: Routledge.

Watkins, Nayo. 2002. "Researcher. Carpetbag Theater." Performing Communities, ed. Robert Leonard, Ann Kilkelly, Linda Burnham, e Steve Durland. http:// www.communityarts.net.

Zollar, Jawole Willa Jo. 2003. Interview by author. 15 Agosto. New York. 